\title{
Two Satellite RNAs Found in Cucumber Mosaic Virus Strain Y
}

\author{
Kazuo NAKASHIMA*,** and Yoshio EHARA*
}

\begin{abstract}
Two satellite RNAs were found in cucumber mosaic virus strain Y (CMV-Y) propagated in Nicotiana tabacum cv. Ky 57 in our laboratory; a larger molecular weight satellite RNA (Sat I) and a smaller one (Sat II). In virus from Ky 57 tobacco leaves which had been inoculated with genomic RNAs (RNAs 1-3) of the CMV, the satellite RNAs were not detected. This virus we termed CMV(-Sat). Symptoms on Ky 57 tobacco infected with $\mathrm{CMV}(-$ Sat $)$ or with CMV(-Sat) + the satellite RNA(s) (Sat I or/and Sat II) were similar. However, addition of the satellite RNAs reduced yield of the virus by about half. The virus purified from tobacco ( $N$. tabacum cvs. Ky 57 and Xanthi nc) leaves inoculated with CMV(-Sat)+Sat I contained only Sat I even after successive passages of the virus in tobaccos. The virus purified from tobaccos inoculated with CMV (-Sat $)+$ Sat II contained both Sat I and Sat II, and Sat I became predominant after repeated passages of the virus in tobaccos. When tomato (Lycopersicon esculentum cv. Fukuju-nigo) was inoculated with CMV(-Sat), ordinary mosaic symptoms appeared with no necrotic symptoms. When the tomato was inoculated with CMV(-Sat) + the satellite RNAs, lethal necrosis appeared. The lethal necrosis was more severe when CMV(-Sat) was mixed with Sat I than when mixed with Sat II, and in these cases virus purified from the tomato expressing lethal necrosis symptoms contained only Sat I. Thus, it was suggested that Sat I was primarily involved in the tomato necrosis syndrome.
\end{abstract}

(Received March 22, 1989)

Key words: cucumber mosaic virus strain Y, two satellite RNAs, biological role.

\section{INTRODUCTION}

Cucumber mosaic virus (CMV) contains at least four RNA species. Some strains have five RNA species. These species were designated RNA 1-5, in order of decreasing molecular weight $^{16)}$. The three largest RNAs (RNA 1-3) are required for infection. RNA 4 is a subgenomic RNA generated from RNA 3 and codes for the viral coat protein. The fifth RNA has been referred to as a satellite RNA and designated CARNA 5 (CMV-associated RNA 5) by Kaper $^{9}$. This RNA is not required for replication of CMV but is depended upon CMV for its replication and encapsidation ${ }^{4,11,20,24)}$. Moreover, these satellite RNA have little sequence homology with the genomic RNAs ${ }^{2,5,14,21)}$.

The satellite RNAs often affect symptom expression of CMV in some host plants, and have been extensively studied ${ }^{6,7,10,12,13,26)}$. Kaper and Waterworth first pointed out that the presence of satellite RNA in preparations of CMV strain S (CMV-S) resulted in tomato necrosis ${ }^{12)}$. Takanami reported that a culture of CMV strain Y (CMV-Y) isolated in Japan contained a satel-

* Laboratory of Plant Pathology, Faculty of Agriculture, Tohoku University, Tsutsumidori Amamiya, Sendai 980, Japan 東北大学農学部

** Present address: Tropical Agriculture Research Center, Ministry of Agriculture, Forestry and Fisheries, Tsukuba 305, Japan 現在: 農林水産省熱帯農業研究センター 
lite RNA and also it induced tomato necrosis ${ }^{24}$. Recently, Kaper et al. reported that when the CMV-Y (Japanese strain) was propagated in Xanthi nc tobacco, two species of the satellite RNA were detected, and a smaller molecule satellite RNA correlated positively with the increasing severity of tomato necrosis ${ }^{8}$.

Two satellite RNAs were found in CMV-Y propagated in $N$. tabacum cv. Ky 57 in our laboratory. Some properties including host reactions of the satellite RNAs seemed to differ from those reported previously. Thus, biological roles of the satellite RNAs are described in this paper.

\section{MATERIALS AND METHODS}

Virus and plants. $\mathrm{CMV}-\mathrm{Y}^{25}$ ) was maintained in tobacco (Nicotiana tabacum L. cv. Ky 57) plants grown in a growth cabinet (light intensity 12,000 lux at $28 \mathrm{C}$ for $14 \mathrm{hr}$ light and at $20 \mathrm{C}$ for $10 \mathrm{hr}$ dark periods). The virus was purified from the inoculated leaves essentially by the method of Scott ${ }^{22}$ ) followed by sucrose density gradient centrifugation. The purified virus was suspended in $10 \mathrm{mM}$ phosphate buffer, $\mathrm{pH} 8.0$, and stored at $-20 \mathrm{C}$ until use. In this experiment, tobacco ( $N$. tabacum L. cvs. Ky 57 and Xanthi nc) and tomato (Lycopersicon esculentum cv. Fukuju-nigo) were used. Tobacco plants were grown in a growth cabinet mentioned above and fully expanded leaves were inoculated at the 9th leaf stage. Tomato plants were grown in a green house and the cotyledons and the 1st leaf of the plants were inoculated at the 2-leaf stage.

Extraction of virus RNA. Virus RNA was extracted from purified virus as previously reported ${ }^{3,23}$. Then, purified virus was dissociated in a solution containing $2 \%$ sodium dodecyl sulfate (SDS), $30 \mathrm{mM}$ sodium phosphate, and ethylenediamine-tetraacetic acid (EDTA), $\mathrm{pH} 7.2$, at $60 \mathrm{C}$ for $5 \mathrm{~min}$. Protein was removed by phenol extraction and RNA was precipitated with $70 \%$ ethanol at $-80 \mathrm{C}$ overnight and pelleted by centrifugation. The RNA was dried, suspended in distilled water and stored at $-20 \mathrm{C}$ until use.

Agarose gel electrophoresis of RNA. RNA was denatured in $2.2 \mathrm{M}$ formaldehyde at $65 \mathrm{C}$ for $10 \mathrm{~min}$. The sample was electrophoresed in $1.7 \%$ agarose tube gels $(7 \mathrm{~mm} \times 9 \mathrm{~cm})$

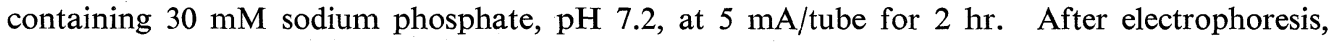
the gels were stained with $0.005 \%$ Stainsall (Kodak) in $50 \%$ formamide and destained in water under a dim light ${ }^{3,23)}$.

Polyacrylamide gel electrophoresis $(P A G E)$ of $R N A$. Analysis of satellite RNA was carried out essentially according to Avila-Rincon et al. ${ }^{1}$ The RNA was suspended in a solution containing $66 \%$ formamide, $1 \mathrm{M}$ urea, $2.5 \mathrm{mM}$ EDTA and $0.075 \%$ xylene cyanol, and cooled rapidly after heating at $65 \mathrm{C}$ for $5 \mathrm{~min}$. The sample was electrophoresed in $5 \%$ polyacrylamide gels (acrylamide:bis $=39: 1$ ) containing $40 \mathrm{mM}$ Tris, $20 \mathrm{mM}$ sodium acetate, $2 \mathrm{mM}$ EDTA, pH 7.8 (TAE) and $8 \mathrm{M}$ urea at $10 \mathrm{~V} / \mathrm{cm}$ for $6 \mathrm{hr}$. After electrophoresis, the gels was stained as described above.

RNA component composition. After stained, the gels were scanned with a chromatoscanner (Shimazu CS-900) at $550 \mathrm{~nm}$ and each RNA component was estimated quantitatively by the method of Lot and Kaper ${ }^{15)}$.

Separation of $\boldsymbol{R N A}$. RNA extracted from purified virus was rapidly cooled after incubation at $70 \mathrm{C}$ for $5 \mathrm{~min}$, layered onto a $10-40 \%$ sucrose density gradient containing $0.1 \%$ SDS, TAE and centrifuged at $190,000 \times g$ for $4 \mathrm{hr}$. Genomic RNAs and satellite RNA separated in the gradient were fractionated by an ISCO fractionator monitored at $254 \mathrm{~nm}$. The RNAs were suspended in $70 \%$ ethanol, stored at $-80 \mathrm{C}$ overnight and centrifuged at 10,000 $\times g$ for $10 \mathrm{~min}$. The resultant pellet was suspended in TAE containing $1.1 \%$ SDS and recentrifuged in the sucrose density gradient. The procedure was repeated 5 times to separate genomic RNA and a mixture of the satellite RNAs ${ }^{11)}$. The two species of satellite RNA were separated by electrophoresis on polyacrylamide gels, then the RNAs were stained with $10 \mu \mathrm{g} / \mathrm{ml}$ 
ethidium bromide containing $1 \mathrm{mM}$ EDTA for $20 \mathrm{~min}$. The RNAs were extracted from gels by the method of McDonell et al. ${ }^{19)}$ The RNA-containing gel sections were cut out, put into cellulose tubing bags, and dialysed against TAE, and the RNA was electroeluted at $10 \mathrm{~V} / \mathrm{cm}$ for 30 min into the dialysing bag. Ethanol was added to the RNA fraction to a final concentration of $70 \%$, and the mixture was stored at $-80 \mathrm{C}$ overnight and centrifuged at $10,000 \times g$ for $10 \mathrm{~min}$. The resultant pellet (RNA) was dried and suspended in distilled water. The procedure was repeated 2 times and the RNA was stored at $-80 \mathrm{C}$ until use.

Inoculation. Virus and the satellite RNA(s) were suspended in phosphate buffer (10 $\mathrm{mM}, \mathrm{pH}$ 8.0) and rub-inoculated with sterilized carborundum onto the plants.

\section{RESULTS AND DISCUSSION}

When the CMV RNA denatured with formaldehyde was electrophoresed in $1.7 \%$ agarose, five RNA species (RNAs 1-5) were separated (Fig. 1A). This method seemed suitable to separate high molecular weight RNAs such as RNA 1-4 of CMV, but did not resolve the low molecular satellite RNAs. However, when satellite RNA was denatured with formamide and urea and electrophoresed in $5 \%$ polyacrylamide gel, two RNA species were apparent (Fig. 1B). The higher and lower molecular satellite RNAs were designated Sat I and Sat II, respectively. In the present virus propagated in Ky 57 tobacco leaves, usually the amount of Sat I appeared to be larger than that of Sat II.

Genomic RNAs (RNAs 1-3) of the virus were isolated by repeated sucrose density gradient centrifugation as described above and inoculated onto Ky 57 tobacco leaves. The progeny virus contained only RNAs 1-4 with no detectable satellite RNA (Fig. 2, lane 1). This preparation was designated CMV(-Sat). In the following experiments, $50 \mu \mathrm{g} / \mathrm{ml}$ of CMV(-Sat) and that mixed with $10 \mu \mathrm{g} / \mathrm{ml}$ of Sat I or/and $10 \mu \mathrm{g} / \mathrm{ml}$ of Sat II were used as inocula. When Ky 57 tobacco leaves were inoculated with only CMV(-Sat) or with CMV (-Sat) mixed with Sat I or/and Sat II, all plants showed similar symptoms consisting of chlorotic spots on the in-

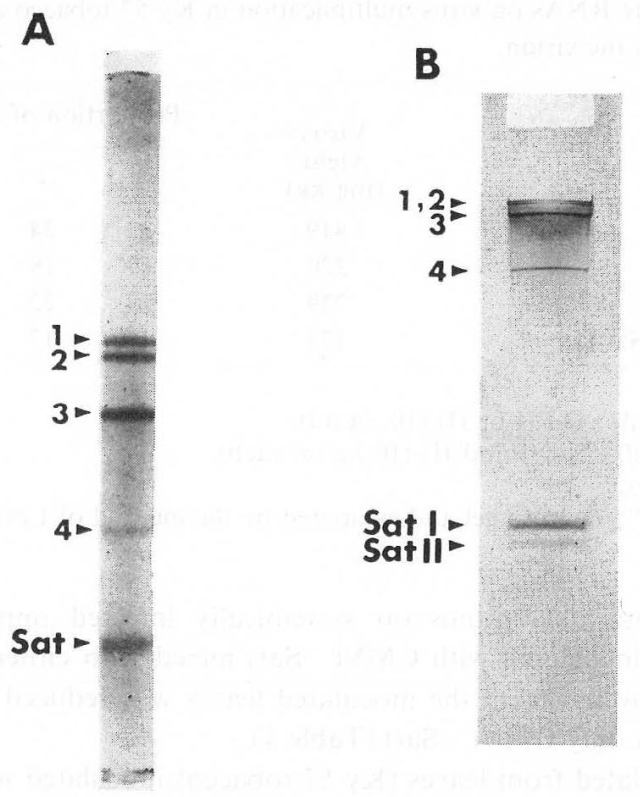

Fig. 1. Electrophoretic analysis of CMV-Y RNAs in: A. 1.7\% agarose gel, B. $5 \%$ polyacrylamide gel. Arrows 1, 2, 3, 4 and Sat indicate positions of CMV-RNA 1, 2, 3, 4 and satellite RNA, respectively. 


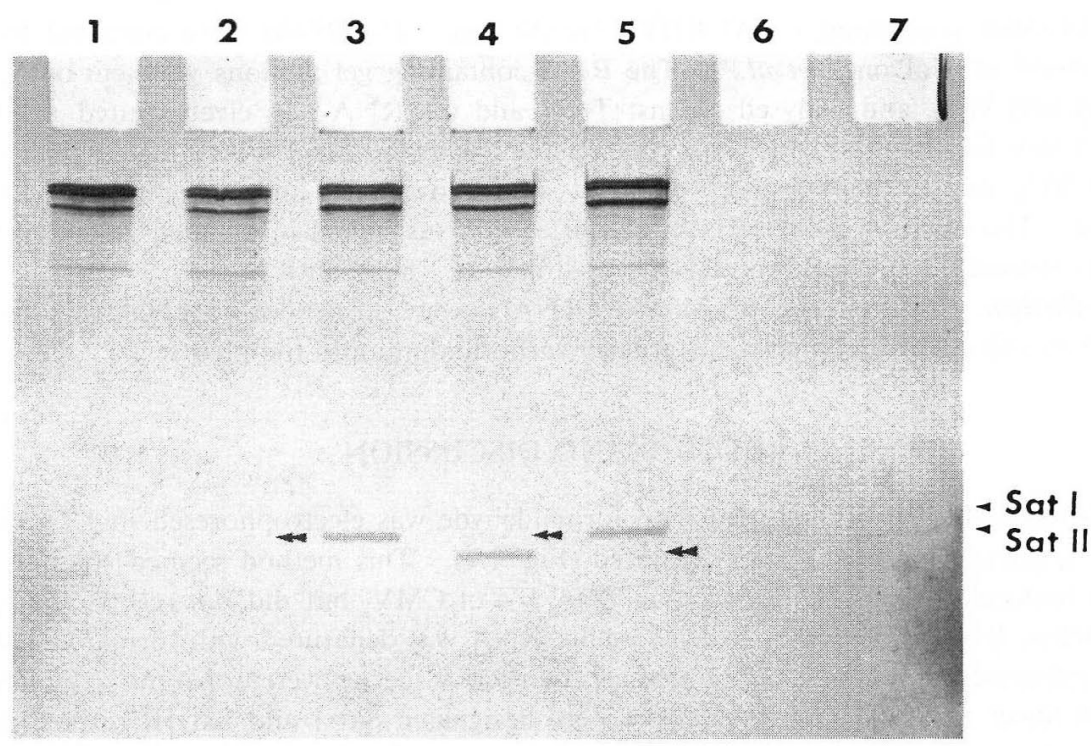

Fig. 2. Electrophoretic analysis (5\% PAGE) of satellite RNA species in the virus from Ky 57 tobacco leaves inoculated with each inoculum. 1. RNA species of CMV(-Sat). 2. RNA species in progeny virus from tobacco leaves inoculated with $\operatorname{CMV}$ (-Sat) $(50 \mu \mathrm{g} / \mathrm{ml})$. 3. Satellite RNAs in progeny virus from tobacco leaves inoculated with $\operatorname{CMV}(-$ Sat $)(50 \mu \mathrm{g} / \mathrm{ml})+$ Sat I $(10 \mu \mathrm{g} / \mathrm{ml})$. 4. Satellite RNAs in progeny virus from tobacco leaves inoculated with CMV $(-$ Sat $)(50 \mu \mathrm{g} / \mathrm{ml})+$ Sat II $(10 \mu \mathrm{g} / \mathrm{ml})$. 5. Satellite RNAs in progeny virus from tobacco leaves inoculated with $\mathrm{CMV}(-\mathrm{Sat})(50 \mu \mathrm{g}$ / $\mathrm{ml})+$ Sat I $(10 \mu \mathrm{g} / \mathrm{ml})+$ Sat II $(10 \mu \mathrm{g} / \mathrm{ml})$. 6, 7. Sat I and Sat II as markers, respectively. Double arrows ( ) show the position of a faint band which is unclear in the figure.

Table 1. Effect of satellite RNAs on virus multiplication in Ky 57 tobacco and on the proportions of RNA species in the virion

\begin{tabular}{|c|c|c|c|c|c|c|}
\hline \multirow{2}{*}{ Inoculum } & \multirow{2}{*}{$\begin{array}{l}\text { Virus d) } \\
\text { yield } \\
(\mathrm{mg} / \mathrm{kg})\end{array}$} & \multicolumn{5}{|c|}{ Proportion of RNA components $(\%)^{\theta)}$} \\
\hline & & 1 & 2 & 3 & 4 & Sat \\
\hline CMV (-Sat $\left.)^{a}\right)$ & 419 & 32 & 34 & 24 & 8 & 2 \\
\hline CMV $(-$ Sat $)+$ Sat I b $)$ & 220 & 19 & 18 & 34 & 7 & 22 \\
\hline $\operatorname{CMV}(-\mathrm{Sat})+$ Sat II b $)$ & 239 & 22 & 22 & 30 & 6 & 20 \\
\hline CMV $(-$ Sat $)+$ Sat I +Sat II $\left.{ }^{c}\right)$ & 173 & 16 & 17 & 35 & 7 & 25 \\
\hline
\end{tabular}

a) $50 \mu \mathrm{g} / \mathrm{ml}$.

b) CMV (-Sat) $(50 \mu \mathrm{g} / \mathrm{ml})+$ Sat (I or II) $(10 \mu \mathrm{g} / \mathrm{ml})$.

c) $\operatorname{CMV}(-\mathrm{Sat})(50 \mu \mathrm{g} / \mathrm{ml})+$ Sat (I and II) $(10 \mu \mathrm{g} / \mathrm{ml}$ each).

d) From inoculated leaves.

e) Electrophoresed in $1.7 \%$ agarose gel and estimated by the method of Lot and Kaper. ${ }^{15)}$

oculated leaves and mosaic symptoms on systemically infected upper leaves. While, when the tobacco leaves were inoculated with CMV(-Sat) mixed with either Sat I or Sat II or both, the amount of virus recovered from the inoculated leaves was reduced by about half compared with that inoculated with only $\mathrm{CMV}(-$ Sat) (Table 1$)$.

In progeny virus isolated from leaves (Ky 57 tobacco) inoculated with $\mathrm{CMV}(-\mathrm{Sat})$, a small amount of satellite RNA (Sat I) was detected (Table 1, Fig. 2, lane 2). This fact probably shows that a trace amount of the satellite RNA was contaminated in genomic RNAs which were used for making CMV(-Sat). In progeny virus isolated from the leaves inoculated with CMV $(-$ Sat $)$ 
mixed with Sat I or/and Sat II, a large amount of satellite RNA was detected. The amount was estimated to be about 1/5-1/4 of total virus RNA. In these cases, RNAs 1 and 2 appeared to decrease in amounts in proportion to increase in RNA 3 and satellite RNAs (Table 1). When tobacco leaves were inoculated with CMV(-Sat) mixed with Sat I, only Sat I was detectable as satellite RNA (Fig. 2, lane 3), and when inoculated with CMV(-Sat) mixed with Sat II, Sat II was detectable with a small amounts of Sat I (Fig. 2, lane 4). When inoculated with CMV (-Sat) mixed with both Sat I and Sat II, satellite RNA in the progeny virus consisted of Sat I and Sat II (Fig. 2, lane 5), and the quantitative proportion of Sat I and Sat II varied with each experiment.

When virus from Ky 57 tobacco inoculated with CMV(-Sat) mixed with Sat I was propagated in Ky 57 tobacco, the progeny virus contained only Sat I as the satellite RNA throughout three passages. In contrast, by inoculation with CMV(-Sat) mixed with Sat II, a small amount of Sat I together with Sat II was detected in the first passage, and Sat I increased after the second passage. At the third passage, the amount of Sat I appeared to be larger than that of Sat II (Fig. 3). Similar results were also obtained using Xanthi nc tobacco plants.

Tomato (cv. Fukuju-nigo) plants inoculated with CMV(-Sat) showed ordinary mosaic symptoms without necrosis. The satellite RNA (Sat I) was detected in virus purified from the mosaic leaves, though it was far less in amount than that from tobacco inoculated with CMV (-Sat) (data not shown). All tomato plants inoculated with CMV(-Sat) mixed with the satellite RNA (Sat I or Sat II) began to exhibit necrosis within 15 days after inoculation, and later they were dead. The death advanced more rapidly by addition of Sat I than Sat II. Besides, only Sat I was detected in virus purified from tomato leaves exhibiting necrosis even if inocula contained either Sat I or Sat II (Fig. 4).

Takanami ${ }^{24}$ and Masuta et al. ${ }^{17,18)}$ have reported that satellite RNA found in a culture of CMV-Y consisted of one species and caused a brilliant yellow symptom on tobaccos ( $N$. tabacum cvs. Bright Yellow and Xanthi nc, N. glutinosa and $N$. sylvestris). The satellite RNA reduced

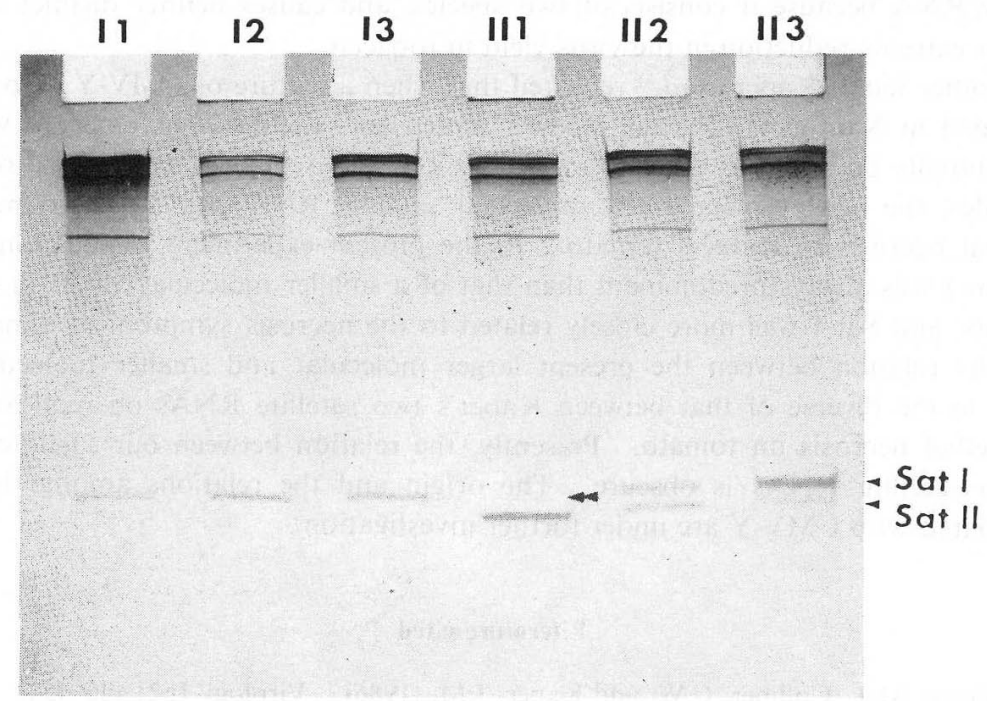

Fig. 3. Electrophoretic analysis (5\% PAGE) of satellite RNA species in RNA preparation of the virus purified from successive passages in Ky 57 tobacco. I1, I2 and I3 denote the satellite RNA species in virus from the first, second and third passages, respectively, using CMV(-Sat) $(50 \mu \mathrm{g} / \mathrm{ml})+$ Sat I $(10 \mu \mathrm{g} / \mathrm{ml})$ as a starting inoculum. II1, II2 and II3 denote the satellite RNA species in virus from the first, second and third passages, respectively, using CMV(-Sat) $(50 \mu \mathrm{g} / \mathrm{ml})+$ Sat II $(10 \mu \mathrm{g} / \mathrm{ml})$ as a starting inoculum. Double arrow; see Fig. 2. 


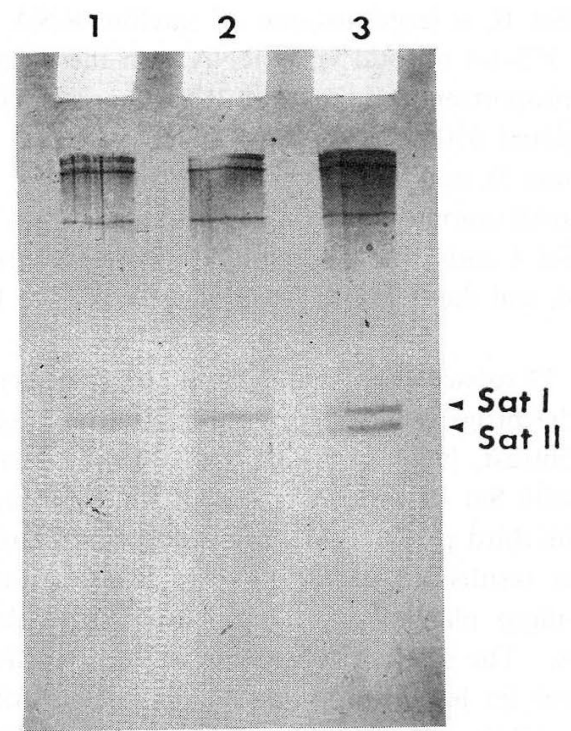

Fig. 4. Electrophoretic analysis (5\% PAGE) of the satellite RNA species in the virus from tomato (cv. Fukuju-nigo) plants inoculated with CMV(-Sat) + Sat I or Sat II and began to show lethal necrosis. 1. Inoculation with $\mathrm{CMV}(-$ Sat $)(50 \mu \mathrm{g} / \mathrm{ml})+$ Sat I $(10 \mu \mathrm{g} / \mathrm{ml})$. 2. Inoculation with $\mathrm{CMV}(-\mathrm{Sat})(50 \mu \mathrm{g} / \mathrm{ml})+$ Sat II $(10 \mu \mathrm{g} / \mathrm{ml})$. 3. Sat I and Sat II RNAs as markers.

the yields of virus on tobacco by about 95 percent $^{24)}$ and induced a severe necrotic symptom or ultimate death on tomato (cvs. Rutgers and Best of All) ${ }^{18,24}$. Our satellite RNA differs from their satellite RNA because it consists of two species, and causes neither distinct alteration in symptom nor extreme reduction in the virus yield in tobacco.

On the other hand, Kaper et al. ${ }^{8)}$ reported that when a culture of CMV-Y (Japanese strain) was propagated in Xanthi nc tobacco, a lower molecular satellite RNA emerged with the satellite RNA initially present and the amount of this new RNA increased following repeated passages. Besides, the newly emerged low molecular satellite RNA was shown to be capable of eliciting lethal necrosis in Rutgers tomato. In the present experiment, replication of a larger molecular Sat I was always predominant than that of a smaller molecular Sat II in tobacco and tomato plants, and Sat I was more closely related to the necrosis symptom in tomato than Sat II. Thus, the relation between the present larger molecular and smaller molecular satellites seems to be in the reverse of that between Kaper's two satellite RNAs on replication and induction of lethal necrosis on tomato. Presently, the relation between our satellite RNAs and Kaper's two satellite RNAs is obscure. The origin and the relations among these satellite RNAs associated with CMV-Y are under further investigation.

\section{Literature cited}

1. Avila-Rincon, M.J., Collmer, C.W. and Kaper, J.M. (1986). Virology 152: 446-454.

2. Diaz-Ruiz, J.R. and Kaper, J.M. (1977). Ibid. 80: 204-213.

3. Ehara, Y., Nakashima, K. and Suzuki, T. (1987). Tohoku J. Agric. Res. 37: 43-48.

4. Gonsalves, D., Provvidenti, R. and Edwards, M.C. (1982). Phytopathology 72: 1533-1538.

5. Gould, A.R., Palukaitis, P., Symons, R.H. and Mossop, D.W. (1978). Virology 84: 443-455.

6. Kaper, J.M. (1983a). In Plant Molecular Biology, Vol. XII (Goldberg, R.B. ed.). Alan R. Liss, Inc., New York. pp. 81-100.

7. Kaper, J.M. (1983b). Plant Mol. Biol. Reptr. 1: 49-54. 
8. Kaper, J.M., Duriat, A.S. and Tousignant, M.E. (1986). J. gen. Virol. 67: 2241-2246.

9. Kaper, J.M. and Tousignant, M.E. (1977). Virology 80: 186-195.

10. Kaper, J.M. and Tousignant, M.E. (1984). Endeavour 8: 194-200.

11. Kaper, J.M., Tousignant, M.E. and Lot, H. (1976). Biochem. Biophys. Res. Commun. 72: 12371243.

12. Kaper, J.M. and Waterworth, H.E. (1977). Science 196: 429-431.

13. Kaper, J.M. and Waterworth, H.E. (1981). In Handbook of Plant Virus Infections. Comparative Diagnosis (Kurstak, E. ed.). Elsevier/North-Holland Biomedical Press, Amsterdam. pp. 257-332.

14. Lot, H., Jonard, G. and Richards, K.E. (1977). FEBS Lett. 80: 395-400.

15. Lot, H. and Kaper, J.M. (1976). Virology 74: 209-222.

16. Lot, H., Marchoux, G., Marrou, J., Kaper, J.M., West, C.K., van Vloten-Doting, L. and Hull, R. (1974). J. gen. Virol. 22: 81-93.

17. Masuta, C., Komari, T. and Takanami, Y. (1989). Ann. Phytopath. Soc. Japan 55: 49-55.

18. Masuta, C., Kuwata, S. and Takanami, Y. (1988). Ibid. 54: 332-336.

19. McDonell, M.W., Simon, M.N. and Studier, F.W. (1977). J. Mol. Biol. 110: 119-146.

20. Mossop, D.W. and Francki, R.I.B. (1978). Virology 86: 562-566.

21. Palukaitis, P. and Zaitlin, M. (1984). Ibid. 132: 426-435.

22. Scott, H.A. (1963). Ibid. 20: 103-106.

23. Shirako, Y. and Ehara, Y. (1986). J. gen. Virol. 67: 1237-1245.

24. Takanami, Y. (1981). Virology 109: 120-126.

25. Tomaru, K. and Hidaka, Z. (1960). Bull. Hatano Tobacco Expt. Sta. 46: 143-149.

26. Yoshida, K., Goto, T. and Iizuka, N. (1985). Ann. Phytopath. Soc. Japan 51: 238-242.

\section{和 文 摘 要}

中島一雄・江原淑夫 : キュウリモザイクウイルス Y 系統に見いだされた 2 種のサテライト RNA

本研究室に括いて，タバコ (Nicotiana tabacum 品種 Ky 57) で継代したキュウリモザイクウイルス黄斑系 (CMV-Y) に2 種のサテライトRNA が見いだされた（分子量の大きいほうを Sat I, 小さいほうを Sat II とよぶ)。本ウイルスのゲノム RNA (RNA 1 3) 接種により得られたウイルスにサテライトRNA は検出 されなかった（このウイルスをCMV (-Sat) とよぶ)。CMV (-Sat) を接種したタバュ (Ky 57) 接種葉の病 徵はサテライト RNA を加えたものとほとんど変りなかった。しかし後者では増殖量は半減した。CMV (一Sat)+Sat I で接種した場合, 継代してもサテライトは Sat I のみが検出された。一方, CMV (一Sat)+Sat II で接種した場合, Sat I と Sat II が検出され, 継代するにつれて Sat I が優勢となった。CMV (一Sat) を接種したトマト(Lycopersicon esculentum 品種 福寿 2 号) には通常のモザイク症状が発現し， えそは生 じなかった。CMV (一Sat)+サテラィトRNA で接種したとき，全身えそが生じた。えそは Sat II よりも Sat I の混合により強く現れた。このえそ発現トマトからはサテライトとして Sat I のみが検出され, トマ トの竞発現には Sat I が深く関わっていることが示唆された。 